Document downloaded from:

http://hdl.handle.net/10251/75666

This paper must be cited as:

Igual Ramo, M.; García Martínez, EM.; Camacho Vidal, MM.; Martínez Navarrete, N. (2013). Jam processing and storage effects on b-carotene and flavonoids content in grapefruit. Journal of Functional Foods. 5(2):736-744. doi:10.1016/j.jf f.2013.01.019.

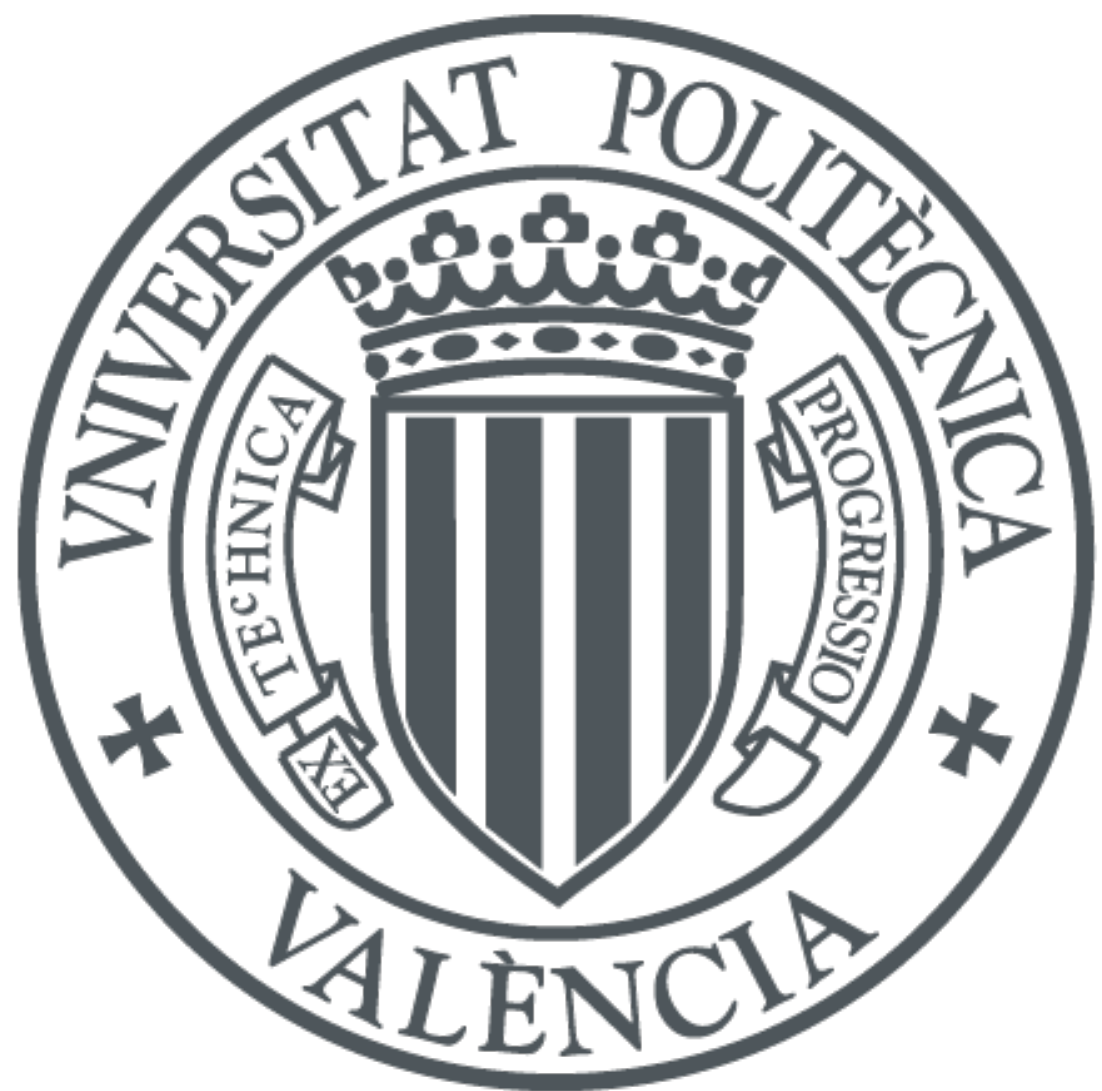

The final publication is available at

https://dx.doi.org/10.1016/j.jff.2013.01.019

Copyright Elsevier

Additional Information 


\title{
Jam processing and storage effects on $\beta$-carotene and flavonoids content in
}

grapefruit.

\author{
Igual, M., García-Martínez, E., Camacho, M.M., Martínez-Navarrete, N.*
}

Universitat Politècnica de València, Food Technology Department, Food Investigation and Innovation Group, Camino de Vera s/n, 46022 Valencia, Spain

\section{Abstract}

Grapefruit phytochemicals ( $\beta$-carotene and flavonoids) stability after different jam processing was evaluated. Osmotic dehydration, microwave energy and conventional heating techiques have been used to obtain jam. $\beta$-carotene and individual flavonoids were analyzed by HPLC technique. The results showed that jam obtained from osmodehydrated fruit (ODJ) is the only that preserved completely the $\beta$-carotene content. All processes of production of jam significantly decreased the content of narirutin (NAT), poncirin (PON), naringenin (NAG) and quercetin (QUER), while naringin (NAR) remained stable. Jams obtained by applying a heat treatment showed significant lower values of NAG and QUER in comparison with ODJ. The jam obtained from osmodehydrated fruit, without being submitted to any heat treatment, showed at the end of storage the highest contents of naringin, hesperidin, neohesperidin, didymin, quercetin, poncirin and the total sum of analysed flavonoids. In general, the phytochemical loss in jams as a consequence of processing was lower than those provoked by storage effect.

Keywords: grapefruit jam, osmotic dehydration, microwaves, flavonoids, $\beta$-carotene, 3 phytochemicals

\footnotetext{
* Corresponding author: +34 96387 9362; fax: +34 9638773 69. E-mail address: nmartin@tal.upv.es (Martínez-Navarrete, N).
} 


\section{Introduction}

Numerous epidemiological studies suggest that diets rich in phytochemicals and antioxidants perform a protective role on health and diseases. Frequent consumption of fruits and vegetables is associated with a lowered risk of cancer, heart disease, hypertension and stroke (Marco et al., 1997; Vinson et al., 2001; Wolfe \& Liu, 2003). Phytochemicals are some of the bioactive non-nutrient compounds present in fruits, vegetables, grains and other plant foods that have been associated with the protection of human health against chronic degenerative diseases (Kalt, 2001; Martínez-Navarrete et al., 2008; Shahidi \& Naczk , 1995).

Cells in humans are constantly exposed to a variety of oxidizing agents. These agents may be present in air, food and water, or they may be produced by metabolic activities within cells. The key factor is to maintain a balance between oxidants and antioxidants to sustain optimal physiologic conditions in the body. Overproduction of oxidants can cause an imbalance, leading to oxidative stress, especially in chronic bacterial, viral and parasitic infections (Liu \& Hotchkiss, 1995). Moreover, oxidative stress can cause oxidative damage to large biomolecules such as proteins, DNA and lipids, resulting in an increased risk of cancer and cardiovascular disease (Ames, \& Gold, 1991; Ames et al., 1993). To prevent or slow down the oxidative stress induced by free radicals, sufficient amounts of antioxidants need to be consumed. Fruits and vegetables contain a wide variety of phytochemicals compounds, such as phenolics and carotenoids, that may help to protect the cellular systems from oxidative damage and to decrease the risk of chronic diseases (Liu, 2003).

Citrus fruits are especially valued for their antioxidant capacity, which has been linked to the presence in them of vitamin $\mathrm{C}$, phenols (mainly flavonoids and some phenolic acids) and terpenes (carotenoids). Flavones are phenolic compounds that exist almost exclusively in citrus plants and they have been of particular interest due to their documented broad spectrum of biological activity, including anti-inflammatory, anti- 
51 carcinogenic, and anti-atherogenic properties, among others (Shiming et al., 2009). Citrus

52 fruits are also particularly rich in pectin, implicated in colon cancer prevention and 53 regulation of glucose and cholesterol level (Wang et al., 2007), and in minerals. The 54 amount of each of these compounds found is specific to the citrus fruit and the variety 55 considered. Among them, the orange is the most consumed and therefore has been the 56 most studied. However, the grapefruit is a citrus fruit also of interest, with important health benefits. According to some authors (Peterson et al., 2006a, b; Xu et al., 2008), grapefruit 58 is an excellent source of phytochemicals, more than orange, tangerine, lemon or lime, 59 emphasis in the presence of naringin (which owes its bitter taste) and neohesperidin and, 60 in pink varieties, also $\beta$-carotene (pro-vitamin A) and lycopene, responsible for its colour. 61 Despite the high functional value of the grapefruit, it is not widespread consumed, probably because of its strong bitter taste. In this sense processed products that mask this flavour in some extent, such as jams, could be even more acceptable than the fresh fruit.

64 In traditional jam manufacture, all the ingredients are mixed in adequate rates and the mix is concentrated by applying an intense thermal treatment to reach the required final soluble solid content. This process also implies an undesirable impact in colour, flavour and nutritional and functional value of the fruit due to the long time and high temperature reached in the cooking process. An alternative for jam formulation is to use dehydrated fruit obtained by osmotic dehydration (OD) at mild temperature. This technique has been proposed to obtain fruit products without being so aggressive to the antioxidant 71 compounds in the fruit (García-Martínez et al., 2002; Igual et al., 2010; Shi et al., 1996). 72 OD consists of immersing the fruit in a highly concentrated solution in order to promote the water loss of the fruit cells (Lazarides, 2001). The high concentration of solutes reached on

74 the surface of the product contributes to obtain a product with good taste, flavour and 75 colour, to improve the cellular structure and to prevent the pigments and aromatic compounds loss also as the browning of the products (Moraga et al., 2000; Moreno et al., 
77 2000; Shi et al., 1996). Another proposed alternative for jam cooking has been the employ

78 of a faster heating method as it is the application of microwave energy (Igual et al., 2010).

79 Microwave absorption provokes internal water heating and evaporation, greatly increasing

80 the internal pressure and concentration gradients and thus the effective water diffusion. As

81 a consequence, shorter processing time is required and higher product quality may be

82 achieved. The different processing technique may affect in a different way to their

83 bioactive compounds. For this reason, the most suitable method to process each product

84 should be selected depending on the type of compounds considered to be the most 85 important (Siriamornpuna et al., 2012). In this sense, the aim of this work was to evaluate 86 the influence of processing (osmotic dehydration, microwave energy and conventional 87 heating) and storage on flavonoids and $\beta$-carotene content of grapefruit jam.

\section{Materials and methods}

\subsection{Raw materials}

92 Grapefruits (Citrus paradise var. Star Ruby) from the city of Murcia (Spain) were 93 purchased from a local supermarket. Fruit pieces were peeled and cut perpendicularly to 94 the fruit axis into $10 \mathrm{~mm}$ thick half-slices. Food grade commercial sucrose was used to prepare conventional and microwave (MW) jams. In the case of the jam obtained by

96 osmotic dehydration, an osmotic solution (OS) was prepared by mixing sucrose with 97 distilled water until it was completely dissolved, forming a $65^{\circ}$ Brix syrup. In this case, 98 citrus peel pectin (60\% degree of esterification, Fluka Biochemika, Switzerland) was used 99 as a gelling agent.

100 
102 The following procedures were applied to obtain a $40-60^{\circ}$ Brix product, as described by the

103 Spanish quality norm for fruit jam (BOE, 1990). In all the cases, the obtained jams were

104 placed in sterile glass jars and stored at room temperature for $24 \mathrm{~h}$ till analysis. Water

105 activity $\left(\mathrm{a}_{\mathrm{w}}\right)$ and $\mathrm{pH}$ of the jams were analysed by means of a dew point hygrometer FA-st

106 Lab, GBX (Bourg de Peage, France) and a CRISON pH-meter (Barcelona, Spain),

107 respectively. Each analysis was carried out in triplicate.

108

109 2.2.1. Conventional process

110 Fresh fruit (FG) (67 g grapefruit/100 g mixture) was pre-cooked at $85^{\circ} \mathrm{C}$ for $10 \mathrm{~min}$, added

111 to the sugar and potassium sorbate (32.99 and $0.01 \mathrm{~g} / 100 \mathrm{~g}$ mixture, respectively) and

112 cooked at $95-100^{\circ} \mathrm{C}$ for 20 min longer. An electrical food processor (Thermomix TM 21,

113 Vorwerk, Spain) was used for the process. The conventional jam obtained with this 114 procedure was named CJ.

115

$116 \quad$ 2.2.2. Microwave process

117 FG (67 g grapefruit/100 g mixture) was pre-cooked (900 W, $5 \mathrm{~min}$ ), added to the sugar and 118 potassium sorbate (32.99 and $0.01 \mathrm{~g} / 100 \mathrm{~g}$ mixture, respectively) and cooked at $900 \mathrm{~W}$ for

11910 min longer. A household microwave-air oven (Moulinex 5141 AFW2, Barcelona, Spain)

120 was used to obtain this jam, named MWJ.

121

$122 \quad$ 2.2.3. Osmotic process

123 Half slices of peeled grapefruit were placed in a $65^{\circ}$ Brix OS (ratio OS:fruit 5:1) for 10 min

124 at room temperature and 50 mbar pressure and then maintained for 10 min longer at 125 atmospheric pressure. After that, the fruit pieces and the OS were heated to $40{ }^{\circ} \mathrm{C}$ (water 126 bath P-Selecta Precisterm, Barcelona, Spain) with continuous stirring of the OS(200 rpm, 127 Heidolph Instruments, RZR 2020, Schwabach, Germany) for 3 h, to reach grapefruit with 
128 about $30^{\circ}$ Brix according (Igual et al., 2010). Osmo-dehydrated grapefruit pieces (ODG),

129 potassium sorbate $(0.01 \mathrm{~g} / 100 \mathrm{~g} \mathrm{jam})$ and pectin $(1 \mathrm{~g} / 100 \mathrm{~g}$ jam $)$ were ground with the

130 required part of the OS to obtain jam with $60 \mathrm{~g}$ fresh fruit/100 $\mathrm{g}$ jam, taking into account

$131{ }^{\circ}$ Brix of ODG and ${ }^{\circ}$ Brix of the OS. The jam thus obtained was referred as ODJ.

132

133 2.2.4. Combined osmotic-microwave process

134 Jams obtained from osmo-dehydrated grapefruit, as described in Section 2.2.3, were

135 cooked in the microwave-air oven at $900 \mathrm{~W}$ for 5 min to obtain OD+MWJ samples.

136

\subsection{Storage conditions}

138 Jams were stored for 3 months at room temperature, except ODJ which was stored at $4{ }^{\circ} \mathrm{C}$

139 (García-Martínez et al., 2002; Igual et al., 2011a). Analyses were carried out after 1, 7, 15,

$14030,45,60,75$ and 90 days of storage.

141

142 2.4. Analysis

143 2.4.1. $\beta$-carotene

144 Samples were homogenized. Ethanol (4 mL) was added to $2 \mathrm{~g}$ homogenate paste and the 145 mixture was centrifuged (Selecta Medifriger-BL, Barcelona, Spain) at $2000 \mathrm{rpm}$ for $3 \mathrm{~min}$ 146 at $4{ }^{\circ} \mathrm{C}$. The supernatant was filtered through a Whatman No.1 paper and $0.5 \mathrm{~mL}$ of $\mathrm{n}$ 147 hexane were added to the filtrate and mixed. $\beta$-carotene was extracted twice in the hexane 148 phase and the collected extract was dried under a stream of liquid nitrogen. Dried extract

149 was solubilized in $0.2 \mathrm{~mL}$ methanol. $\beta$-carotene content was determined and quantified by

150 HPLC. The HPLC (Jasco, Cremella, Italy) equipment consisted of a ternary pump (Jasco

151 PU- 1580 HPLC pump), a gradient generator (LG-1580-02 Ternary Gradient Unit), 152 Ultrabase-C18 column $(5 \mu \mathrm{m}, 4.6 \times 250 \mathrm{~mm})$ and a UV-visible detector (MD-1510) with a 153 range of measurement wavelength of 190 to $650 \mathrm{~nm}$. The mobile phase was composed 
154 methanol: acetonitrile: chloroform (47:42:11, v/v/v), volume injection $20 \mu \mathrm{L}$ and flow rate 1

$155 \mathrm{~mL} / \mathrm{min}$. The $\beta$-carotene detection was at $436 \mathrm{~nm}$ and $25^{\circ} \mathrm{C}$ (Munzuroglu et al., 2003).

156 Standard curve of this reference compound (Fluka-Biochemika, Milwaukee, WI, USA) was

157 used to quantify. The results were expressed as $\mathrm{mg}$ of $\beta$-carotene per 100 grams of fresh

158 sample, considering the percentage of fresh grapefruit in the sample. Changes in this

159 compound along storage were expressed as the compound variation $\left(\Delta \mathrm{M}_{\mathrm{i}}\right)$ referred to the

160 fresh grapefruit content, according to equation (1):

$$
\Delta \mathrm{M}_{\mathrm{i}}=\frac{\left(\mathrm{M}_{\mathrm{i}}^{\mathrm{t}}-\mathrm{M}_{\mathrm{i}}^{0}\right)}{\mathrm{M}_{\mathrm{i}}^{\mathrm{FG}}}
$$

162

163

164

165

166

167

168

169

170

171

172

173

174

where: $\mathrm{M}_{\mathrm{i}}^{\mathrm{t}}$ : mass of compound $\mathrm{i}$ in the sample / $\mathrm{g}$ fresh grapefruit at storage time $t, \mathrm{M}_{\mathrm{i}}{ }^{0}$ : mass of compound $\mathrm{i}$ in the sample / $\mathrm{g}$ fresh grapefruit at storage time 0 and $\mathrm{Mi}^{\mathrm{FG}}$ : mass of compound $\mathrm{i} / \mathrm{g}$ fresh grapefruit.

\subsubsection{Flavonoids}

The extraction of flavonoids was carried out following the procedure proposed by TomásBarberán et al. (2001). It consisted of homogenizing $35 \mathrm{~g}$ of the sample (T25 Janke and Kunkel turrax) for $5 \mathrm{~min}$ with $40 \mathrm{~mL}$ of methanol, $10 \mathrm{~mL}$ of double distilled water and $\mathrm{NaF}$ to inactivate polyphenol oxidases and to prevent phenolic degradation. The homogenate was centrifuged (Selecta Medifriger-BL, 10,000 rpm, $10 \mathrm{~min}, 4{ }^{\circ} \mathrm{C}$ ) to obtain the supernatant that was filtered through a $0.45 \mu \mathrm{m}$ membrane filter. HPLC method and instrumentation was: Ultrabase-C18, $5 \mu \mathrm{m}(4.6 \times 250 \mathrm{~mm})$ column (Análisis Vínicos, Tomelloso, Spain); mobile phase was composed of methanol and water and a linear gradient elution was performed starting at 30:70 to reach 100:0 at $70 \mathrm{~min}$, volume injection $25 \mu \mathrm{L}$ and flow rate $1 \mathrm{~mL} / \mathrm{min}$. Chromatograms were recorded at 286, 284 and $254 \mathrm{~nm}$ and at $25^{\circ} \mathrm{C}$. The standard curves of the reference flavonoids, narirutin (NAT), naringin (NAR), hesperidin (HES), neohesperidin (NEOH), didymin (DID), poncirin (PON), naringenin 
179 (NAG) and quercetin (QUER) (Extrasynthese, France) were used to quantify the

180 flavonoids. Naphthalene was used as internal standard (Peiró, 2007; Igual et al., 2011b).

181 The results were expressed as $\mathrm{mg}$ of each flavonoid per 100 grams of fresh sample,

182 considering the percentage of fresh grapefruit in the sample. Changes in each compound

183 along storage were expressed as the compound variation $\left(\Delta \mathrm{M}_{\mathrm{i}}\right)$ referred to the fresh

184 grapefruit content, according to equation (1).

185

2.5. Statistical analysis

187 Significant differences among treatments and storage time were evaluated by means of

188 the corresponding analysis of variance (ANOVA) performed by using Statgraphics Plus

189 5.1. Values of $p<0.05$ were considered to represent a significant effect. A Principal

190 Component Analysis (PCA) with varimax rotation was applied to the values of the

191 flavonoid content, using SPSS program version 16.0.

192

\section{3. Results and Discussion}

194 Significant differences were found among water activity of all the jams, the values being $1950.945,0.942,0.924$ and 0.922 (standard deviation 0.003 in all the cases) for ODJ,

196 OD+MWJ, MWJ and CJ, respectively. As regards $\mathrm{pH}$ (standard deviation 0.02 in all the 197 cases), no significant differences were found between ODJ, OD+MWJ (3.39 and 3.40,

198 respectively) while it was significantly different from that of MWJ (3.27) and CJ (3.25).

199 Some authors have indicated that freezing, pasteurization, boiling and microwave cooking 200 generally reduce the antioxidant capacity of fruits (Aziz et al., 1998; Gil-Izquierdo et al., 201 2002; Guyot et al., 2003). Phenolics and carotenoids have been described as antioxidant 202 compounds. Processing of fruits normally leads to a decrease in the concentration and a 203 change in the composition of phytochemicals including flavonoids (Tsao et al., 2006).

204 Carotenoids are lost between 5 and $40 \%$, depending on the conditions of food preparation 
and preservation (Belitz \& Grosch, 1997, Eitenmiller \& Laden, 1999). The impact of the 206 different processes carried out in the present work to obtain jam on these compounds is 207 shown in Table 1, where the mean values of $\beta$-carotene and flavonoids content of FG, 208 ODG and jams, all of them referred to $100 \mathrm{~g}$ of fresh grapefruit, appear. Table 2 shows the 209 loss of each analyzed compound, compared to the content present in the fresh fruit, due to 210 processing and storage.

211 The $\beta$-carotene is the major dietary precursor of vitamin A ( $\mathrm{Xu}$ et al., 2006), becoming 212 retinol inside the human body (Belitz \& Grosch, 1997). Besides its function as pro-vitamin 213 A, the functional significance of this carotenoid is also due to its antioxidant action 214 (Bushway, 1986). As is shown in Table 1, in this study FG showed values in the same 215 order to those obtained in previous studies for red grapefruit of the same variety (0.2-1.3 216 mg/100 g; Ladaniya, 2008; Rojas, 2004; Rouseff et al., 1992). After osmotic-dehydration, 217 the sample retained the $\beta$-carotene content. When comparing the jams, ODJ was the only 218 one that completely preserved the $\beta$-carotene content showing only $4.19 \%$ loss of this 219 compound. Nevertheless the sample subjected to combined treatment (OD+MWJ) 220 presented the greatest loss $(29 \mathrm{~g} \beta$-carotene loss $/ 100 \mathrm{~g} \beta$-carotene present in the fresh 221 fruit, Table 2). The jams obtained by applying an intense thermal treatment (CJ and MWJ) 222 showed similar values of this compound, with about $17.5 \mathrm{~g} \beta$-carotene loss $/ 100 \mathrm{~g} \beta$ 223 carotene present in the fresh fruit (Tables 1 and 2 ). In general, $\beta$-carotene is sensitive to 224 oxygen and light, oxidation losses occurring especially at high temperatures (Lesková et 225 al., 2006). On the other hand, in the absence of these two factors, $\beta$-carotene is quite 226 stable at elevated temperatures (cooking), producing in this case isomerization and 227 fragmentation.

228 Figure 1 shows the $\beta$-carotene change in the jams during storage period, referred to the content in the fresh sample. $\beta$-carotene losses were faster during the first week in the case of ODJ and during the first 15 days in the rest of the jams. From that moment onwards, the 
$231 \beta$-carotene content remained constant until the end of storage in all the jams. After 3 232 months, the samples that were subjected to more intense heat treatments during jam 233 preparation presented a loss between 33 and 38\% (Table 2); lower values than these were 234 observed for jams made from osmodehydrated fruit (55-56\%). Although the OD treatment 235 maintained the $\beta$-carotene content of the fresh grapefruit, greater losses during storage 236 were observed in OD and OD+MWJ samples. This could be related to the greater $a_{w}$ and $237 \mathrm{pH}$ of the jams obtained from OD fruit. As it can be observed in Table 1, the most 238 abundant flavonoid in the fresh grapefruit was NAR followed by NAT, QUER and NAG, 239 results that closely agree with other studies (Gorinstein et al., 2006; Igual et al., 2011b; 240 Peterson et al., 2006a, Ross et al., 2000; Vanamala et al., 2006). In general, osmotic 241 dehydration of the fruit caused no changes in the concentration of the studied flavonoids. 242 Only a significant HES decrease was detected. All the processes carried out to obtain 243 jams significantly $(p<0.05)$ decreased the content of NAT, PON, NAG and QUER. NAR 244 remained stable during all treatments without showing significant $(p>0.05)$ differences with 245 the fresh grapefruit. Jams obtained by heating (CJ, MWJ and OD+MWJ) showed 246 significant $(p<0.05)$ lower values of NAG, DID and QUER as compared to ODJ while NAT, 247 HES and NEOH were worse preserved in ODJ. The loss of each compound due to the jam 248 elaboration process appears in Table 2. As regards the total flavonoids in the samples, 249 calculated as the sum of the individual analysed flavonoids, fresh and OD grapefruit 250 contained about $140 \mathrm{mg} / 100 \mathrm{~g}$ fresh fruit and all the jams presented a significant $(p<0.05)$ 251 lower content, ODJ followed by MWJ being the ones with more flavonoids (about 124 $252 \mathrm{mg} / 100 \mathrm{~g}$ fresh fruit). A total flavonoids loss caused by processing of $9-18 \mathrm{~g} / 100 \mathrm{~g}$ total 253 flavonoids present in the fresh fruit was quantified (Table 2).

254 The change in content of flavonoids in the obtained jams during storage appears in 255 Figures 2 and 3. In general, losses of all the studied flavonoids, except in the case of PON, 256 could be observed. In all the jams, PON remained stable during the first month of storage 
and thereafter, it increased. This increase can be attributed to a chemical transformation of 258 NAG and NAR (Igual et al., 2011b). During the first 45 days of storage, NAT and NAG remained stable and from that moment onwards, its content decreased until the end of 260 storage. The greatest loss of HES, NEOH and DID occurred in all the samples during the 261 first 15 days. From that moment, the content of these flavonoids remained stable until the 262 end of storage. Intensive thermal treatments (CJ and MWJ) lead to greater losses in NAR, 263 HES and NEOH during storage, while jams made from osmodehydrated fruit lost more 264 QUER and NAG in this period (Table 2). Figure 4 shows the variation in the sum of all the 265 flavonoids considered referred to the content in the fresh fruit, during 3 months of storage. 266 Jams presented losses during the storage period in the range of $21.5-29.3 \mathrm{~g}$ total 267 flavonoids $/ 100 \mathrm{~g}$ total flavonoids present in the fresh fruit (Table 2). These losses were 268 more marked from day 45 (Figures 2 and 3). The more intensively treated samples (CJ 269 and MWJ) showed the greatest loss during the studied period.

270 The evolution of flavonoids content can be easily observed by means of the PCA carried 271 out with the values corresponding to all the jams at different storage times (Figure 5). The 272 first two factors showed eigenvalues higher than 1. The consideration of both factors 273 accounted for $83.79 \%$ of the total variability. The first factor $(F 1)$, explaining $51.14 \%$ of the 274 variability, was associated with DID ( $r=0.94)$, NEOH ( $r=0.93)$, NAR $(r=0.93)$, HES $(r=0.90)$, 275 QUER ( $r=0.75)$ and NAG $(r=0.74)$ values. The second factor $(F 2)$ accounted for $26.65 \%$ of 276 the variability and it was mainly associated with PON ( $r=0.94)$ and NAT $(r=0.91)$ values. All 277 the grapefruit jams newly processed showed a higher content of the flavonoids associated 278 with F1 and of NAT but low of PON. During the first month of storage, PON and NAT 279 remained stable while the rest of the flavonoids decreased. From this moment onwards, 280 NAT decreased and PON increased while the other flavonoids did not showed additional 281 changes. Applying a multifactor ANOVA to the values of F1 and F2, it can be observed 282 that both factors are affected by the interaction of the progress of time and the treatment 
applied to obtain jams. F1 decreased more sharply during the first month in $\mathrm{CJ}$ and MWJ

284 as compared to ODJ and OD+MWJ while F2 decreases faster during the last two months

285 in the samples ODJ and OD+MWJ when compared to CJ and MWJ.

286 As can be observed in Table 2, in general the losses of the analyzed compounds in jams 287 caused by processing were lower than those provoked by storage period. As regards the 288 total losses occurred due to both processing and storage, the $\beta$-carotene loss when 289 compared to its content in the fresh fruit was between 53 and $86 \%$, being the combined 290 treatment (OD+MWJ) especially less recommendable to preserve this compound. In the 291 case of flavonoids, these loosses were between 33 and $47 \%$, the greatest ones being 292 showed by the more intense thermally treated jams, especially the one obtained by using 293 the conventional procedure.

\section{Conclusion}

296 Flavonoids of grapefruit are better retained than $\beta$-carotene in jams. The greatest losses of 297 the analyzed compounds occurred during jam's storage and not during the production 298 processing. Taking into account the obtained results, microwave heating may be proposed 299 as a good process, better than osmotic dehydration or conventional heating, to obtain a 300 stable jam. This procedure can best fulfill the commitment process time-functional quality 301 of the stored obtained product. Osmotic dehydration would only be recommended if a 302 ready to eat jam is wanted to be obtained.

\section{Acknowledgment}

305 The authors thank the Ministerio de Educación y Ciencia for the financial support given 306 throughout the Project AGL 2005-05994. 


\section{References}

309

310 Ames, B.N., and Gold, L.S. Endogenous mutagens and the causes of aging and cancer.

311 Mutation Research 250 (1991), pp. 3-16.

313 Ames, B.N., Shigenaga, M.K., and Gold, L.S. DNA lesions, inducible DNA repair, and cell

314 division: the three key factors in mutagenesis and carcinogenesis. Environmental Health 315 Perspectives 101(5) (1993), pp. 35-44.

316

317 Aziz, A.A., Edwards, C.A., Lean, M.E., and Crozier, A. Absorption and excretion of 318 conjugated flavonols, including quercetin-4'-O-glucoside and isorhamnetin-4'-Oglucoside 319 by human volunteers after the consumption of onions. Free Radical Research 29 (1998), 320 pp. 257-269.

322 Belitz, H.D. \& Grosch, W. (1997). Química de los alimentos. $2^{\text {a }}$ Ed. Acribia. Zaragoza.

324 BOE No 130. (1990). Real Decreto 670/1990, de 25 de mayo, por el que se aprueba la norma de calidad para confituras, jaleas y marmalade de frutas, crema de castañas y mermelada de frutas.

328 Bushway, R.J. Determination of $\alpha$ and $\beta$-Carotene in Some Raw Fruits and Vegetables. 329 Journal of Agricultural and Food Chemistry 34 (1986), pp. 409-412.

331 Eitenmiller, R.\& Laden, W.O. (1999). Ascorbic acid. En: R.R. Eitenmiller and W.O. Laden 332 Editores. Vitamin Analysis for the Health and Food Science (pp. 26-228). Boca Raton, FL: 
335 García-Martínez, E., Ruiz-Diaz, G., Martínez-Monzó, J., Camacho, M.M., Martínez-

336 Navarrete, N., and Chiralt, A. Jam manufacture with osmodehydrated fruit. Food Research 337 Internacional 35 (2002), pp. 301-306.

339 Gil-Izquierdo, A., Gil, M.I., and Ferreres, F. Effect of processing techniques at industrial 340 scale on orange juice antioxidant and beneficial health compounds. Journal of Agricultural 341 and Food Chemistry 50 (2002), pp. 5107-5114.

343 Gorinstein, S., Huang, D., Leontowicz, H., Leontowicz, M., Yamamoto, K., Soliva-Fortuny, 344 R., Martin-Belloso, O., Martinez-Ayala, A. L., and Trakhtenberg, S. Determination of 345 Naringin and Hesperidin in citrus fruit by HPLC. The antioxidant potential of citrus fruit. 346 Acta Chromatographica 17 (2006), pp. 108-124.

348 Guyot, S.; Marnet, N.; Sanoner, P., and Drilleau, J.F.. Variability of the polyphenolic 349 composition of cider apple (Malus domestica) fruits and juices. Journal of Agricultural and 350 Food Chemistry 51 (2003), pp. 6240-6247.

Igual, M., Contreras, C., and Martínez-Navarrete, N. Non-conventional techniques to 353 obtain grapefruit jam. Innovative Food Science \& Emerging Technologies 11(2) (2010), pp. $354 \quad 335-341$. Igual, M., Castelló, M.L., Ortolá, M.D., and Andrés, A. Some quality aspects of persimmon 357 jam manufactured by osmotic dehydration without thermal treatment. International Journal 358 of Food Engineering, 7(5) (2011a), 9, pp. 1-15. 
360 Igual, M., García-Martínez, E., Camacho, M.M., and Martínez-Navarrete, N. Changes in 361 flavonoid content of grapefruit juice caused by thermal treatment and storage. Innovative 362 Food Science and Emerging Technologies 12 (2011b), pp. 153-162.

364 Kalt. W. Health functional phytochemicals of fruit. Horticultural Reviews, 27 (2001), pp. $365 \quad 269-315$.

367 Ladaniya, M. (2008). Citrus fruit: biology, technology and evaluation. Academic Press. San 368 Diego, CA, USA.

Lazarides, H.N. (2001). Reasons and Possibilities to Control Solids Uptake Turing Osmotic

371 Treatament of Fruits and Vegetables. In P. Fito, A. Chiralt, J. M. Barat, J. Spiess and S.

372 Beshnilian. Osmotic Dehydration and Vacuum Impregnation. Food Preservation 373 Technology Series. Vol. 4. (pp. 33-42).

375 Lesková, E., Kubiková, J., Kovácikova, E., Kosicka, M., Porubska, J., and Holcikova, K.. 376 Vitamin losses: Retention during heat treatment and continual changes expressed by 377 mathematical models. Journal of Food Composition and Analysis 19 (2006), pp. 252-276.

379 Liu, R.H. and Hotchkiss J.H. Potential genotoxicity of chronically elevated nitric oxide: a 380 review. Mutation Research 339 (1995), pp. 3-89.

382 Liu, R.H.. Health benefits of fruit and vegetables are from additive and synergistic 383 combinations of phytochemicals. American Journal Clinical Nutrition 78 (2003), pp. 517S384520 s. 
386 Marco, D. B. F., Joseph, V., and John, K. Mechanisms of disease: antioxidants and 387 atherosclerotic heart disease. New England Journal of Medicine 337(6) (1997), pp. 408388416.

390 Martínez-Navarrete, N., Camacho, M.M., and Martínez-Lahuerta, J.J. Los compuestos 391 bioactivos de las frutas y sus efectos en la salud. Actividad Dietética 12(2) (2008), pp. 6439268.

394 Moraga, G., Martínez-Navarrete, N., Martínez-Monzó, J., \& Chiralt, A. (2000). Influence of 395 convective and osmotic drying on some color and firmness properties of strawberry. In 396 P.J.A.M. Kerkhof, W.J. Coumans, G.D. Mooiweer. Proceedings of 12th International 397 Drying Symposium (IDS2000). Elsevier Science B.V., Noordwijkerhout, Netherlands.

399 Moreno, J., Chiralt, A., Escriche, I., and Serra, J.A. Effect of blanching/osmotic dehydration 400 combined methods on quality and stability of minimally processed strawberries. Food 401 Research International 33(7) (2000), pp. 609-616.

402

403 Munzuroglu, O., Karatas, F., and Geckil, H. The vitamin and selenium contents of apricot 404 fruit of different varieties cultivated in different geographical regions. Food Chemistry, 405 83(2) (2003), pp. 205-212.

406

407 Peiró, R. (2007). Cambios en los nutrientes y compuestos fitoquímicos asociados al 408 proceso osmótico de frutas y su estabilidad en un producto gelificado. Doctoral Thesis. 409 Universidad Politécnica de Valencia. 
411 Peterson, J., Beecher, G.R., Bhagwat, S.A., Dwyer, J.T,; Gebhardt, S.E., Haytowitz, D.B. 412 and Holden, J.M.. Flavanones in grapefruit, lemons and limes: A compilation and review of 413 the data from the analytical literature. Journal of Food Composition and Analysis 19 414 (2006a), pp. 74-80.

415

416 Peterson, J.; Dwyer, J.; Beecher, G.; Bhagwat, S.; Gebhardt, S.; Haytowitz, D. and 417 Holden, J. Flavanones in oranges, tangerines (mandarins), tangors, and tangelos: a 418 compilation and review of the data from the analytical literature. Journal of Food 419 Composition and Analysis 19 (2006b), pp. S66-73.

421 Rojas, C. Componentes nutricionales y bioactivos en cítricos. Agrícola, 12 (2004), pp. 1842220.

424 Ross, S. A., Ziska, D. S., Zhao, K., and EISohly, M. A. Variance of common flavonoids by 425 brand of grapefruit juice. Fitoterapia 71(2) (2000), pp.154-161.

427 Rouseff, R. L., Sadler, G. D., Putnam, T. J., and Davis, J. E. Determination of $\beta$-carotene 428 and other hydrocarbon carotenoids in Red Grapefruit cultivars. Journal of Agriculture \& 429 Food Chemistry, 40 (1992), pp. 47-51.

430

431 Shahidi F, and Naczk M. (1995). Food phenolics: an overview. In: Shahidi F, Naczk M, 432 eds. Food phenolics: sources, chemistry, effects, applications. Lancaster, PA: Technomic 433 Publishing Company Inc, pp.1-5. 
435 Shi, X. Q., Chiralt, A., Fito, P., Serra, J., Escoin, C., and Gasque, L. Application of osmotic 436 dehydration technology on jam processing. Drying Technology 14(3\&4) (1996), pp. 841437857.

439 Shiming, L., Min-Hsiung P., Chih-Yu, L., Tana, D., Wanga, Y., Shahidid, F., and Ho, C-T. 440 Chemistry and health effects of polymethoxyflavones and hydroxylated 441 polymethoxyflavones. Journal of functional foods 1 (2009) 2-12.

443 Siriamornpuna, S., Kaisoona, O., Meesoc, N. Changes in colour, antioxidant activities and 444 carotenoids (lycopene, b-carotene, lutein) of marigold flower (Tagetes erecta L.) resulting 445 from different drying processes. Journal of functional foods 4 (2012) 757-766.

447 Tomás-Barberán, F. A., Gil, M. I., Cremin, P., Waterhouse, A. L., Hess-Pierce, B., and 448 Kader, A. A. HPLC-DAD-ESIMS analysis of phenolic compounds in nectarines, peaches, 449 and plums. Journal of Agricultural and Food Chemistry, 49 (2001), pp. 4748-4760.

451 Tsao, R., Khanizadeh, S., and Dale A. Designer fruits and vegetables with enriched 452 phytochemicals for human health. Journal of Plant Science 86 (2006), pp. 773-786.

454 Vanamala, J., Reddivari, L., Yoo, K. S., Pike, L. M., and Patil, B. S. Variation in the content 455 of bioactive flavonoid in different brands of orange and grapefruit juices. Journal of Food 456 Composition and Analysis 19 (2006), pp.157-166.

458 Vinson, J., Su, X., Zubik, L., and Bose, P. Phenol antioxidation quantity and quality in 459 foods: fruit. Journal of Agricultural and Food Chemistry 49(11) (2001), pp. 5315-5321. 
461 Wang, Y., Chuang, Y., and Ku, Y. Quantification of bioactive compounds in citrus fruits 462 cultivated in Taiwan. Food Chemistry 102 (2007), 1163-71.

463

464 Wolfe, K. W. X., and Liu, R. H. Antioxidant activity of apple peels. Journal of Agricultural 465 and Food Chemistry 51(3) (2003), pp. 609-614.

466

467 Xu, J., Tao, N., Liu, Q., and Deng, X. Presence of diverse ratios of lycopene/b-carotene in 468 five pink or red-fleshed citrus cultivars. Scientia Horticulturae 108 (2006), pp. 181-184.

469

470 Xu, G., Liu, D., Chen, J., Ye, X., Ma, Y., and Shi, J. Juice components and antioxidant 471 capacity of citrus varieties cultivated in China. Food Chemistry 106 (2008), pp. 545-551.

472

\section{FIGURE CAPTIONS}

474 Figure 1. $\beta$-carotene variations of studied jams along 3 month of storage.

475 Figure 2. Narirutin (NAT), naringin (NAR), naringenin (NAG) and quercetin (QUER) 476 variations of studied jams along 3 month of storage.

477 Figure 3. Hesperidin (HES), neohesperidin (NEOH), didymin (DID) and poncirin (PON) 478 variations of studied jams along 3 month of storage.

479 Figure 4. Principal Component Analysis (PCA) with varimax rotation of the values of 480 flavonoid content corresponding to all the grapefruit jam samples. D0, D30, D60 and D90 481 indicate storage days.

482 Figure 5. Total flavonoids variations of studied jams along 3 month of storage. 


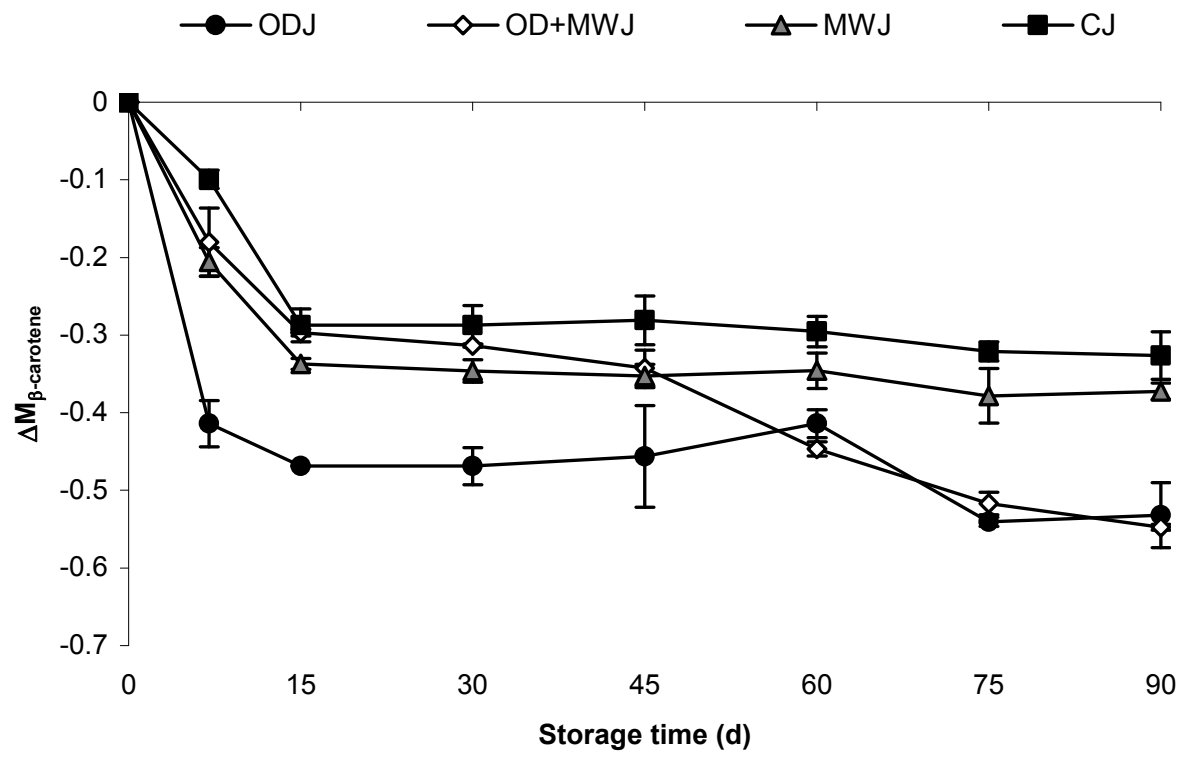

Figure 1 

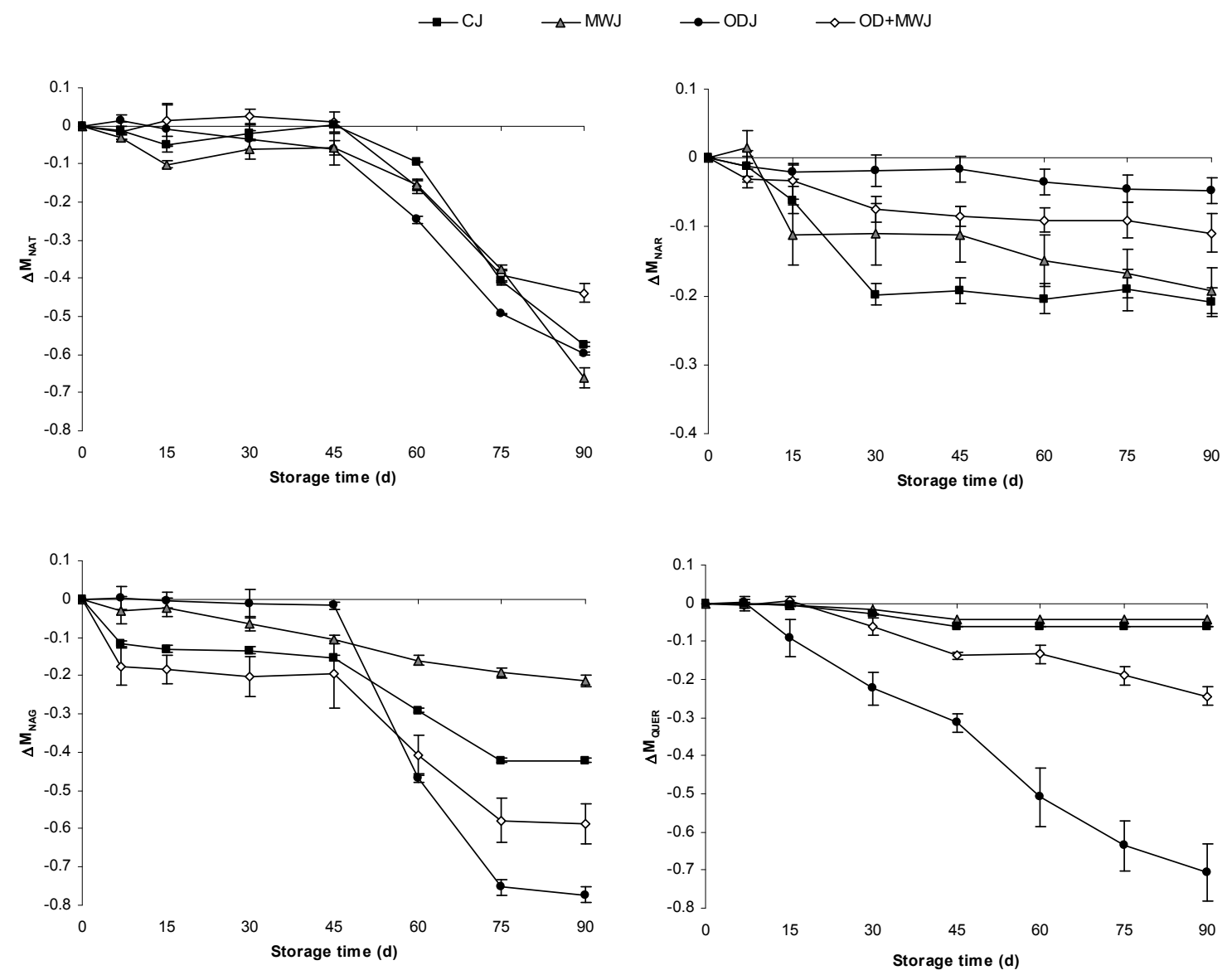

Figure 2 

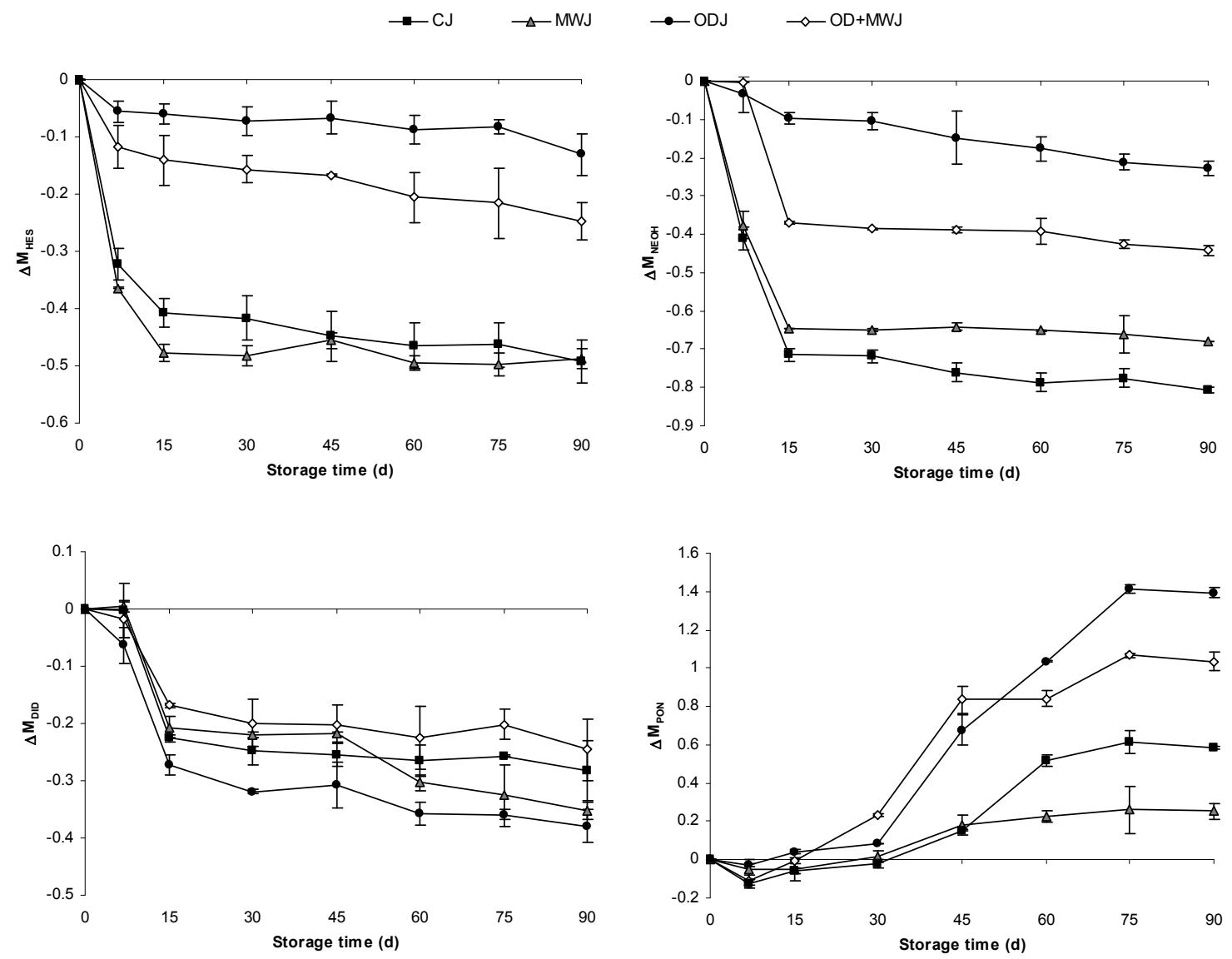

Figure 3 


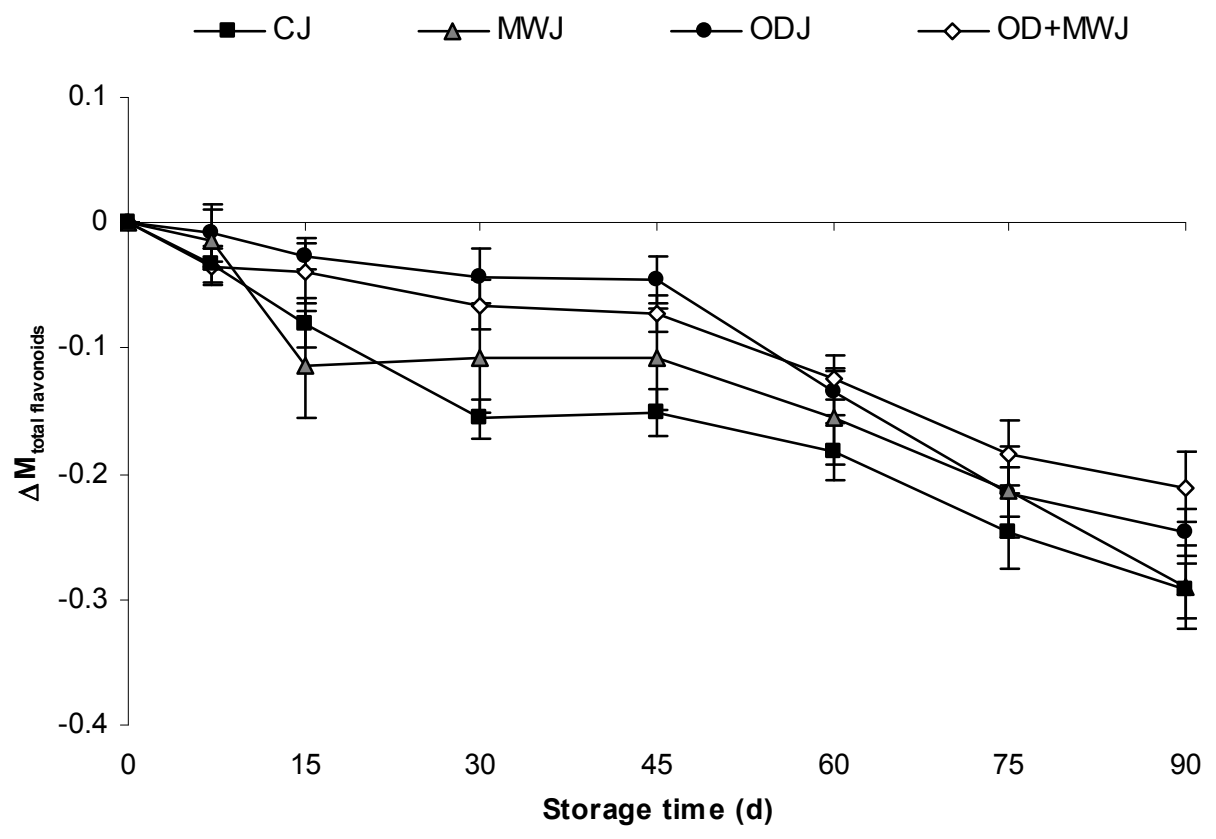

Figure 4 


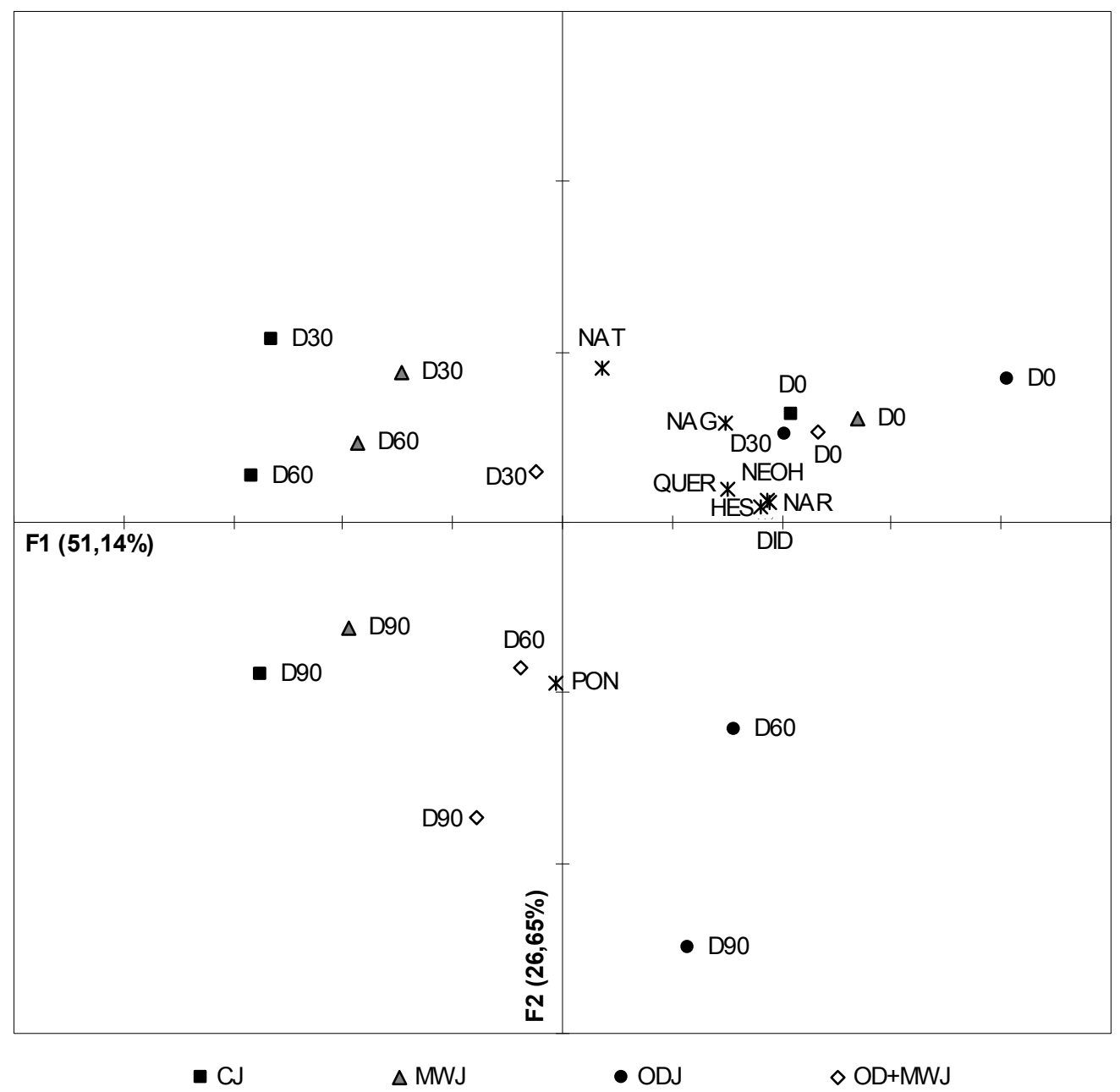

Figure 5 
Table 1. Mean values (with standard deviation) of $\beta$-carotene and flavonoids content ( $\mathrm{mg} / 100$ $g$ fresh fruit) in fresh grapefruit (FG), osmodehydrated grapefruit (ODG) and jams obtained by convencional processing (CJ), microwave (MWJ), from osmodehydrated grapefruit (ODJ) and by combined treatment $(\mathrm{OD}+\mathrm{MWJ})$.

\begin{tabular}{lcccccc}
\hline Compound & FG & ODG & C J & MWJ & ODJ & OD+MWJ \\
\hline$\beta$-carotene & $2.58(0.11)^{\mathrm{a}}$ & $2.60(0.14)^{\mathrm{a}}$ & $2.05(0.02)^{\mathrm{b}}$ & $2.22(0.06)^{\mathrm{b}}$ & $2.48(0.05)^{\mathrm{a}}$ & $1.83(0.02)^{\mathrm{c}}$ \\
NAT & $29.4(0.4)^{\mathrm{a}}$ & $28.7(0.2)^{\mathrm{a}}$ & $24.2(0.3)^{\mathrm{b}}$ & $25.3(0.6)^{\mathrm{b}}$ & $22.2(0.5)^{\mathrm{c}}$ & $20.0(0.8)^{\mathrm{d}}$ \\
NAR & $84(3)^{\mathrm{a}}$ & $82(2)^{\mathrm{a}}$ & $81(5)^{\mathrm{a}}$ & $85(3)^{\mathrm{a}}$ & $81(2)^{\mathrm{a}}$ & $84(6)^{\mathrm{a}}$ \\
HES & $2.40(0.06)^{\mathrm{a}}$ & $1.98(0.09)^{\mathrm{b}}$ & $2.09(0.05)^{\mathrm{b}}$ & $2.24(0.04)^{\mathrm{a}}$ & $1.76(0.05)^{\mathrm{c}}$ & $1.72(0.07)^{\mathrm{c}}$ \\
NEOH & $2.92(0.07)^{\mathrm{ab}}$ & $2.94(0.2)^{\mathrm{a}}$ & $3.13(0.05)^{\mathrm{a}}$ & $3.09(0.09)^{\mathrm{a}}$ & $2.6(0.2)^{\mathrm{c}}$ & $2.64(0.07)^{\mathrm{bc}}$ \\
DID & $1.42(0.03)^{\mathrm{a}}$ & $1.5(0.2)^{\mathrm{a}}$ & $0.95(0.03)^{\mathrm{c}}$ & $1.10(0.02)^{\mathrm{bc}}$ & $1.46(0.02)^{\mathrm{a}}$ & $1.16(0.05)^{\mathrm{b}}$ \\
PON & $1.921(0.010)^{\mathrm{a}}$ & $2.06(0.12)^{\mathrm{a}}$ & $0.47(0.02)^{\mathrm{b}}$ & $0.47(0.09)^{\mathrm{b}}$ & $0.52(0.02)^{\mathrm{b}}$ & $0.60(0.03)^{\mathrm{b}}$ \\
NAG & $8.3(0.2)^{\mathrm{a}}$ & $8.5(0.4)^{\mathrm{a}}$ & $3.49(0.04)^{\mathrm{d}}$ & $3.55(0.04)^{\mathrm{d}}$ & $6.8(0.4)^{\mathrm{b}}$ & $4.9(0.5)^{\mathrm{c}}$ \\
QUER & $11.4(0.2)^{\mathrm{a}}$ & $11.34(0.03)^{\mathrm{a}}$ & $0.70(0.02)^{\mathrm{d}}$ & $0.50(0.04)^{\mathrm{d}}$ & $8.6(0.8)^{\mathrm{b}}$ & $3.1(0.2)^{\mathrm{c}}$ \\
Total Flavonoids & $141(3)^{\mathrm{a}}$ & $139.4(0.8)^{\mathrm{ab}}$ & $116(5)^{\mathrm{d}}$ & $119(7)^{\mathrm{cd}}$ & $129(4)^{\mathrm{bc}}$ & $115(3)^{\mathrm{d}}$ \\
\hline
\end{tabular}

The same letter in superscript within rows indicates homogeneous groups established by the ANOVA $(p<0.05)$.

NAT: narirutin, NAR: naringin, HES: hesperidin, NEOH: neohesperidin, DID: didymin, PON: poncirin, NAG: naringenin y QUER: quercetin 
Table 2. Loss of each analyzed compound, compared to the content of the correponding compounds present in the fresh fruit, due to the process and also to the storage in jams obtained by convencional processing (CJ), microwave (MWJ), from osmodehydrated grapefruit (ODJ) and by combined treatment (OD+MWJ).

\begin{tabular}{|c|c|c|c|c|c|c|c|c|c|c|c|c|}
\hline \multirow[t]{2}{*}{ Compound } & \multicolumn{4}{|c|}{$\begin{array}{l}\text { g component lost during processing } / 100 \mathrm{~g} \\
\text { component present in fresh grapefruit }\end{array}$} & \multicolumn{4}{|c|}{$\begin{array}{l}\text { g component lost during storage } / 100 \mathrm{~g} \\
\text { component present in fresh grapefruit }\end{array}$} & \multicolumn{4}{|c|}{$\begin{array}{c}\text { g component lost during processing and } \\
\text { storage } / 100 \mathrm{~g} \text { component present in fresh } \\
\text { grapefruit }\end{array}$} \\
\hline & CJ & MWJ & ODJ & OD+MWJ & CJ & MWJ & ODJ & OD+MWJ & CJ & MWJ & ODJ & OD+MWJ \\
\hline$\beta$-carotene & 20.83 & 14.13 & 4.19 & 29.19 & 33.63 & 38.36 & 54.82 & 56.42 & 54.46 & 52.49 & 59.01 & 85.61 \\
\hline NAT & 17.75 & 14.20 & 24.42 & 31.92 & 57.47 & 66.08 & 59.79 & 44.27 & 75.21 & 80.28 & 84.21 & 76.19 \\
\hline NAR & 3.11 & 0.009 & -1.87 & 3.03 & 20.98 & 19.31 & 4.80 & 11.20 & 24.09 & 19.32 & 2.93 & 14.23 \\
\hline $\mathrm{NEOH}$ & -7.45 & -6.01 & 12.01 & 9.60 & 80.57 & 67.89 & 22.90 & 44.98 & 73.12 & 61.89 & 34.91 & 54.58 \\
\hline DID & 33.32 & 22.75 & -2.90 & 18.19 & 28.18 & 35.30 & 37.89 & 24.98 & 61.50 & 58.05 & 34.98 & 43.17 \\
\hline PON & 75.38 & 75.38 & 73.13 & 68.98 & -58.39 & -25.47 & -139.33 & -103.15 & 16.99 & 49.91 & -66.19 & -34.16 \\
\hline NAG & 57.78 & 57.04 & 18.20 & 39.72 & 42.22 & 21.37 & 77.26 & 59.67 & 100.00 & 78.41 & 95.45 & 99.39 \\
\hline QUER & 93.85 & 95.58 & 24.53 & 73.36 & 6.15 & 4.42 & 70.67 & 24.13 & 100.00 & 100.00 & 95.20 & 97.48 \\
\hline Total Flavonoids & 17.87 & 15.21 & 8.67 & 18.45 & 29.33 & 29.02 & 24.66 & 21.47 & 47.20 & 44.23 & 33.33 & 39.92 \\
\hline
\end{tabular}

NAT: narirutin, NAR: naringin, HES: hesperidin, NEOH: neohesperidin, DID: didymin, PON: poncirin, NAG: naringenin y QUER: quercetin 